\title{
Changes in physical properties of sandy soil after long-term compost treatment**
}

\author{
József Tibor Aranyos ${ }^{1 *}$, Attila Tomócsik ${ }^{1}$, Marianna Makádi ${ }^{1}$, József Mészáros ${ }^{2}$, and Lajos Blaskó ${ }^{3}$ \\ ${ }^{1}$ CAS Research Institute of Nyíregyháza, University of Debrecen, H-4400 Nyíregyháza, Westsik Vilmos út 4-6, Hungary \\ ${ }^{2}$ Nyírségvíz Ltd., H-4400 Nyíregyháza, Tó utca 5, Hungary \\ ${ }^{3}$ Institute of Water and Environmental Management, University of Debrecen, H-4032 Debrecen, Böszörményi út 138, Hungary
}

Received February 8, 2016; accepted June 28, 2016

\begin{abstract}
A b s t r a c t. Studying the long-term effect of composted sewage sludge application on chemical, physical and biological properties of soil, an experiment was established in 2003 at the Research Institute of Nyíregyháza in Hungary. The applied compost was prepared from sewage sludge (40\%), straw $(25 \%)$, bentonite $(5 \%)$ and rhyolite $(30 \%)$. The compost was ploughed into the $0-25 \mathrm{~cm}$ soil layer every $3 \mathrm{rd}$ year in the following amounts: 0, 9, 18 and $27 \mathrm{Mg} \mathrm{ha}^{-1}$ of dry matter. As expected, the compost application improved the structure of sandy soil, which is related with an increase in the organic matter content of soil. The infiltration into soil was improved significantly, reducing the water erosion under simulated high intensity rainfall. The soil compaction level was reduced in the first year after compost re-treatment. In accordance with the decrease in bulk density, the air permeability of soil increased tendentially. However, in the second year the positive effects of compost application were observed only in the plots treated with the highest compost dose because of quick degradation of the organic matter. According to the results, the sewage sludge compost seems to be an effective soil improving material for acidic sandy soils, but the beneficial effect of application lasts only for two years.

K e y w o r d s: compost, air permeability, bulk density, infiltration, erosion
\end{abstract}

\section{INTRODUCTION}

The increasing needs for agricultural production and for ensuring suitable crop safety require the maintaining and improving of soil fertility. Natural materials, industrial wastes and by-products can be used for improving the physical and chemical properties, and the fertility and biological activity of soils (Angin et al., 2013; Gondek, 2009; Liu et al., 2014, Sánchez de Cima et al., 2015).

\footnotetext{
*Corresponding author e-mail: aranyostibi@gmail.com

**This work was realised in the frame of TÁMOP 4.2.4. A/211-1-2012-0001 'National Excellence Program - Elaborating and operating an inland student and researcher personal support system convergence program'. The project was subsidised by the European Union and co-financed by the European Social Fund.
}

A large part of Hungary (1.4 million ha) is covered with sandy soils. In the region of Nyírség, there are more than 400,000 hectares of sandy soils. The fertility of these soils is limited by their low mineral and organic colloids content and, therefore, by their unfavourable physical and water properties. Due to the high porosity of those soils, organic matter is degraded very quickly (Várallyay, 2005).

The particles of not aggregated sandy soils are very susceptible to compaction. The compaction results in a reduction in pore space, inhibiting the flow of water and air in the soil. The root growth is limited, which can result in a serious yield loss (Civeira, 2010). The improvement of soil structure of sandy soils and reduction of susceptibility to compaction are very important to achieve adequate crop safety (Birkás, 2008).

For increasing the organic and mineral content of these sandy soils many methods were applied, but because of economic aspects these are not used in practice. The range of potentially suitable materials may expand further with using composted sewage sludge to increase the fertility of sandy soils (Adani etal., 2009; MylavarapuandZinati, 2009). In addition, utilisation of sewage sludge compost as an organic manure on arable soils helps to solve serious environmental problems of waste disposal (De O'na et al., 2009).

The physical properties of sandy soils depend greatly on their organic matter content. Soil amendment with compost was found to improve the physical and chemical properties of sandy soils which are poor in mineral and organic colloids. The effects of compost amendment of soil result in increased water- and nutrient-holding capacity (Celik et al., 2004; Weber et al., 2007). In addition, organic matter treatment reduces the soil compaction level and improves the air management (Angin et al., 2013; Mylavarapu and Zinati, 2009).

(C) 2016 Institute of Agrophysics, Polish Academy of Sciences 
Small portable rainfall simulators are very common in soil erosion research because of low costs, easy handling, low water consumption, easy transport and high repetition rates of measurements. These devices are able to reproduce infiltration and interrill-erosion processes in the field (Fister et al., 2011; Iserloh et al., 2012). The erodibility of soils is inversely related to the stability of the soil aggregates (Arthur et al., 2011). An increase was observed in the stability of soil aggregates after compost application (Suzuki et al., 2007; Tejada et al., 2008).

The intensity of changes in soil physical properties depends on the duration of the experiments. Short-term experiments resulted in very important data on the acute effects of sewage sludge compost application, but the regular application is more important in practice. Therefore, our aim was to study the effect of regular sewage sludge compost application in a long-term experiment to find out the long-term changes in soil physical properties. On the basis of our results we determine the stability of these changes and the applicability of sewage sludge compost utilisation to control the erosion of sandy soils.

\section{MATERIALS AND METHODS}

The small-plot sewage sludge compost experiment was established in 2003 at the University of Debrecen CAS Research Institute of Nyíregyháza in Hungary. The objective of the experiment is to determine the effect of long-term application of composted sewage sludge (named as Nyírkomposzt) on the chemical, physical and biological properties of soil and on test plants. The experiment is located at $47^{\circ} 96^{\prime} \mathrm{N}$ latitude and 21072' E longitude and it is situated at elevation of $108 \mathrm{~m}$ a.s.l. The long-term mean annual temperature is $9.8^{\circ} \mathrm{C}$. The mean annual precipitations were $382 \mathrm{~mm}$ in 2012, $485 \mathrm{~mm}$ in 2013 and $539 \mathrm{~mm}$ in 2014 (own data).

The characteristic soil type of the experiment is Arenosol (Dystric Lamellic Arenosols, 87.69\% sand, 2.67\% silt, $9.64 \%$ clay). The main soil parameters before starting the experiment are presented in Table 1 (Makádi, 2010).

The applied compost contained sewage sludge $(40 \%$, mass), straw (25\%, mass), bentonite $(5 \%$, mass) and rhyolite (30\%, mass). Rhyolite has an important element content and, through its structure, provides suitable air conditions and habitat for microorganisms during composting (Coffman and Rasic, 2015). Bentonite is an excellent additive of compost due to its nutrient-adsorbing capacity (Makádi, 2010). The composition of sewage sludge compost met the limit values of the Hungarian regulation (36/2006. (V.18.), Decree of the Ministry of Agriculture). The compost was ploughed into the $0-25 \mathrm{~cm}$ soil layer in five replicates with three test plants (60 plots) in the following amounts: $0,9,18$ and $27 \mathrm{Mg} \mathrm{ha}^{-1}$ of dry matter. Every 3rd year the same rates are always applied on the same plots and the control treatments are always free of compost addition. The plot size was $12 \times 19 \mathrm{~m}$. Test plants were triticale (x Triticosecale Wittmack), maize (Zea mays L.) and green pea (Pisum sativum L.), sown in a crop rotation.

We present the results of the 3rd year after the third sewage sludge compost application in 2009 and the results of the 1st and 2nd years after the fourth compost application in 2012. The main parameters of the applied compost are presented in Table 2 . The compost was analysed by the Central Laboratory of the University of Debrecen according to the Hungarian standards.

T a b l e 1. Soil characteristics before starting the experiment (Makádi, 2010)

\begin{tabular}{|c|c|c|c|c|c|c|}
\hline $\mathrm{pH}_{\mathrm{H}_{2} \mathrm{O}}$ & $\mathrm{pH}_{\mathrm{KCl}}$ & $\begin{array}{c}\text { Soil organic } \\
\text { matter (SOM) } \\
(\%)\end{array}$ & $\begin{array}{c}\mathrm{NO}_{3}-\mathrm{N} \\
\left(\mathrm{mg} \mathrm{kg}^{-1}\right)\end{array}$ & $\begin{array}{l}\mathrm{Al}-\mathrm{P}_{2} \mathrm{O}_{5} \\
\left(\mathrm{mg} \mathrm{kg}^{-1}\right)\end{array}$ & $\begin{array}{c}\mathrm{Al}-\mathrm{K}_{2} \mathrm{O} \\
\left(\mathrm{mg} \mathrm{kg}^{-1}\right)\end{array}$ & $\begin{array}{c}\text { Soil plasticity } \\
\text { according } \\
\text { to Arany }\end{array}$ \\
\hline 6.2 & 5.3 & 0.9 & 9.6 & 240.1 & 183.3 & 28.0 \\
\hline
\end{tabular}

T a b l e 2. Main parameters of sewage sludge compost applied in 2009 and 2012 (own data)

\begin{tabular}{lcc}
\hline Parameter & 2009 & 2012 \\
\hline $\mathrm{pH}_{\mathrm{H}_{2} \mathrm{O}}$ & n.d. & 7.18 \\
Organic matter content $(\%, \mathrm{DM})$ & 20.6 & 27.63 \\
Water soluble total salt content $\left(\mathrm{mg} \mathrm{kg}^{-1}, \mathrm{DM}\right)$ & 30200 & 21500 \\
Total $\mathrm{N}$ content $\left(\mathrm{mg} \mathrm{kg}^{-1}, \mathrm{DM}\right)$ & 11500 & 12600 \\
Total $\mathrm{P}_{2} \mathrm{O}_{5}$ content $\left(\mathrm{mg} \mathrm{kg}^{-1}, \mathrm{DM}\right)$ & 27100 & 10400 \\
Total $\mathrm{K}_{2} \mathrm{O}$ content $\left(\mathrm{mg} \mathrm{kg}^{-1}, \mathrm{DM}\right)$ & 4700 & 2700 \\
\hline
\end{tabular}

n.d. - not determined, DM - dry matter. 
Measurements were carried out in five replicates in the soil physical laboratory of the University of Debrecen, CAS Research Institute of Karcag in Hungary. To determine the bulk density and air permeability, undisturbed soil samples of $100 \mathrm{~cm}^{3}$ in volume were collected from the $5-10 \mathrm{~cm}$ soil layer, because in previous years the collection of soil samples was also done from the same layer. The collection of soil samples was carried out every year after harvesting, in the middle plot of block number 5 (in 2012 from triticale, in 2013 from green pea and in 2014 from maize). The organic carbon content of soil was determined by Tyurin method and from this value the organic matter content was calculated (Buzás, 1993).

The bulk densities of undisturbed soil samples were measured after drying at $105^{\circ} \mathrm{C}$. The air permeability of soil was measured by means of the Eijkelkamp type air permeability apparatus.

The air permeameter apparatus measures the permeability or conductance of an (undisturbed) soil sample at a defined air pressure difference of $1 \mathrm{~cm}$ water column $=$ $0.1 \mathrm{kPa}$. To eliminate the effect of different moisture content, the air permeability was determined uniformly at the moisture content of $\mathrm{pF} 2.3$.

To reproduce infiltration and interrill-erosion processes of soil, the Eijkelkamp type small rainfall simulator was used. The rainfall simulator consists of three parts: a sprinkler with a built-in pressure regulator for the production of the standard rain shower, an adjustable support for the sprinkler; and an aluminium ground frame which is placed on the soil and prevents lateral movement of water from the test plot to the surrounding soil (Kamphorst, 1987).

The measurements with the rainfall simulator were carried out in October 2014, in maize. The moisture content of soil was approx. $8 \%$, vol., in the control and in the compost treatments, too. Before starting the test, the plant residues were removed from the surface, then a slope was artificially created with $15^{\circ}$ incline. The plot design was $25 \times 25 \mathrm{~cm}$ rectangular and the measurements were completed within max. $10 \mathrm{~min}$. The intensity of the simulated rainfall was $185 \mathrm{~mm} \mathrm{~h}^{-1}$, because in preliminary measure- ments under lower rainfall intensity $\left(60 \mathrm{~mm} \mathrm{~h}^{-1}\right)$ a positive effect of compost application was observed. The runoff water was filtered by filter paper in laboratory, then its quantity was measured by measuring cylinders. The amount of infiltration was calculated as the difference between the intensity of simulated rainfall and the amount of runoff. The soil erodibility factor $(\mathrm{K})$ was determined by soil loss using the Universal Soil Loss Equation (USLE) (Wischmeier and Smith, 1978).

To evaluate the results MS Excel and SPSS 13.0 programs were used. The data obtained were statistically analysed by analysis of variance, correlation and linear regression analysis. For pairwise comparison Tukey test were used after ANOVA. The significance level was $p<0.05$.

\section{RESULTS AND DISCUSSION}

Compost application positively affected the soil organic matter content (\%) in the $0-30 \mathrm{~cm}$ soil layer. The organic matter content of soil increased with increasing compost dose. This effect was the most pronounced after compost application in October 2012. It can be explained by the high organic matter content of applied compost. The organic matter content of soil increased in each compost treatment by up to $1.0 \%$ in 2013 . However, significantly higher values of organic matter - as compared with the control $\left(0 \mathrm{Mg} \mathrm{ha}^{-1}\right)$ - were observed only in the plots where the $18 \mathrm{Mg} \mathrm{ha}^{-1}$ compost dose was applied. In 2013, soil organic matter (SOM) content increased also in the control plot. This is probably the effect of triticale root residues, or to the heterogenity of studied soil, because in 2014 the SOM content decreased again to the average value in the control plot.

In the second year (2014), the organic matter content of soil decreased in compost treatments by $0.9-1.0$ to 0.6 $0.9 \%$, as compared with 2013 . The reason for this is the quick degradation of organic matter in sandy soil (Celik et al., 2004). However, significant differences were still observed in the 18 and $27 \mathrm{Mg} \mathrm{ha}^{-1}$ compost treatments compared with the control (Table 3).

T a b l e 3. Changes in soil organic matter $(\mathrm{SOM})$ content in treatments with increasing doses of compost at the depth of 0-30 $\mathrm{cm}$

\begin{tabular}{cccc}
\hline \multirow{2}{*}{$\begin{array}{c}\text { Compost treatment } \\
\left(\text { Mg ha }^{-1}\right)\end{array}$} & 2012 & 2013 & 2014 \\
\cline { 2 - 4 } 0 & $0.67 \pm 0.14 \mathrm{a}$ & $0.78 \pm 0.17 \mathrm{a}$ & $0.54 \pm 0.11 \mathrm{a}$ \\
9 & $0.79 \pm 0.26 \mathrm{ab}$ & $0.94 \pm 0.26 \mathrm{ab}$ & $0.62 \pm 0.12 \mathrm{ab}$ \\
18 & $0.76 \pm 0.28 \mathrm{ab}$ & $1.04 \pm 0.27 \mathrm{~b}$ & $0.78 \pm 0.16 \mathrm{bc}$ \\
27 & $0.96 \pm 0.40 \mathrm{~b}$ & $1.01 \pm 0.30 \mathrm{ab}$ & $0.89 \pm 0.07 \mathrm{c}$ \\
\hline
\end{tabular}

a-c indexes mean different groups of means according to the Tukey test at the significance level of $\mathrm{p}<0.05$, mean \pm standard deviation $(\mathrm{SD})$. 
Sewage sludge and composts made from it are good sources of organic matter because their average organic matter content - depending on the initial materials - are about $20-30 \%$, mass. The organic matter of the compost is a good source of nutrients for soil microbes. The applied compost contained a high amount of fulvic acids (Hanász, 2014) which can be easily mineralised by microbes in soil. The enhancement of soil organic matter content was reported previously as a result of the addition of sewage sludge compost to sandy soil (Arthur et al., 2011; Mylavarapu and Zinati, 2009).

Bulk density depends on soil structure and it is an indicator of soil compaction level (Celik et al., 2004). In the 3rd year of third compost application (2012), there was no significant difference in soil bulk density between the control and the compost treatments (Fig. 1A). However, the compost application had a beneficial effect on soil compaction level in the first year (2013) of the third compost treatment in the $5-10 \mathrm{~cm}$ soil layer. The addition of compost significantly reduced the soil bulk density to 1.4 and $1.35 \mathrm{~g} \mathrm{~cm}^{-3}$ in compost treatments from $1.5 \mathrm{~g} \mathrm{~cm}^{-3}$ measured in control plots.

There was a strong negative correlation $(\mathrm{R}=-0.81)$ between bulk density and organic matter content of the soil, an increase in soil organic matter content causing a decrease in bulk density of the soil. Hemmat et al. (2010) also found a negative correlation $(\mathrm{R}=-0.75)$ between bulk density and soil organic carbon. The decrease in bulk density can be achieved by mixing organic material of compost into the soil (Civeira, 2010; Mylavarapu and Zinati, 2009).

In the second year (2014) after compost application, the bulk density of soil decreased only in the plots where the $27 \mathrm{Mg} \mathrm{ha}^{-1}$ compost dose was applied. The improvement of this soil property observed during the experiment was limited only to a short period of time, and was connected with rapid mineralisation processes (Celik et al., 2004).

In 2013 and 2014 the bulk density of the soil was higher in all treatments than in 2011. In those years the annual precipitation was higher by $100-150 \mathrm{~mm}$ than in 2011 , so the soil compaction level was more pronounced.

Air permeability can be used to determine the pore characteristic of soils. It may be an important indicator of other soil properties, such as soil compaction level and structural stability (Iversen et al., 2001). In our experiment, a significant effect of compost treatment on air permeability of soil was found in 2012 (Fig. 1B). The effect of compost treatment on air permeability was stronger in the first year after compost re-treatment. With a decrease in bulk density, the air permeability of soil increased. The air management of sandy soil was improved as well by the increased total porosity and rate of macropores (Aranyos et al., 2014).

Based on our results, a strong negative linear correlation $\left(R^{2}=-0.54\right)$ was found between bulk density and air permeability of the soil, the decrease in bulk density causing an increase in air permeability of the soil. The decrease/
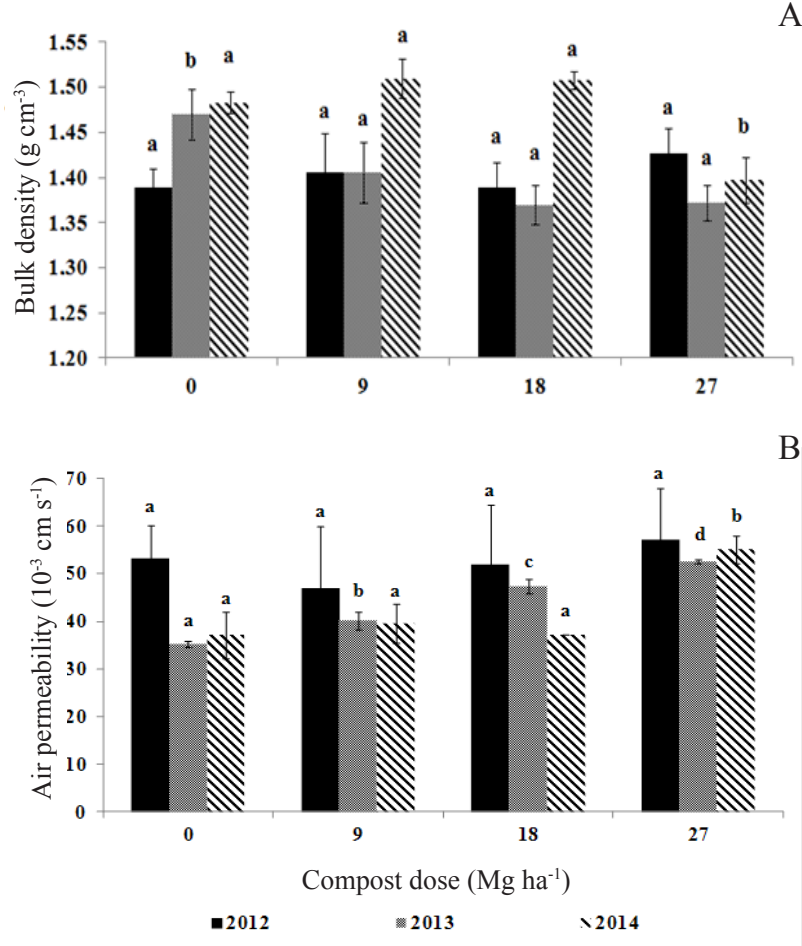

Fig. 1. Changes in: A - bulk density, and B - air permeability of soil in treatments with increasing doses of compost at the depth of 5-10 cm; a-b and a-d indexes mean different groups of means according to the Tukey test at the significance level of $p<0.05$, mean \pm standard deviation (SD).

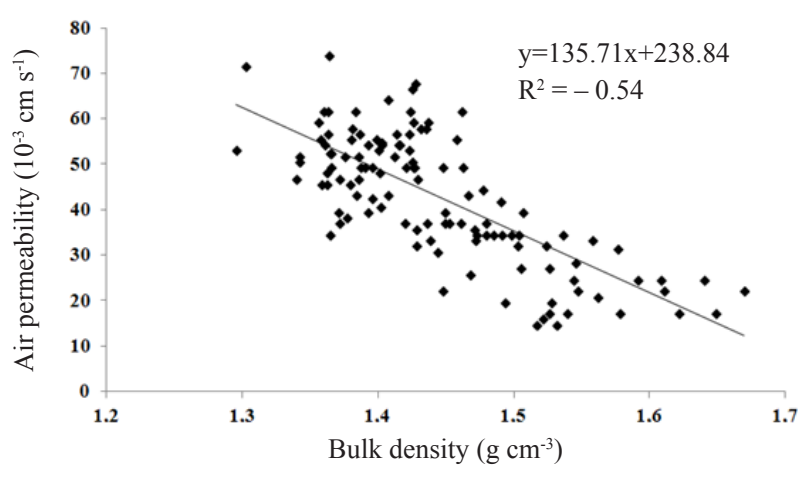

Fig. 2. Relationship between bulk density and air permeability of soil in 2012-2014 ( $\mathrm{N}=120)$.

increase in bulk density $\left(0.1 \mathrm{~g} \mathrm{~cm}^{-3}\right)$ caused approximately a $30 \%$ increase/decrease in air permeability. This relationship indicates that the soil compaction level can significantly affect the flow of air in the soil (Fig. 2).

To assess the influence of compost application on water infiltration, runoff and erosion, a small portable rainfall simulator was used. Water infiltration into the soil was improved by the compost application. The intensity of infiltration did not decrease under the effect of extreme high intensity rainfall $\left(185 \mathrm{~mm} \mathrm{~h}^{-1}\right)$. The rate of infiltration was increased in the compost treatments by the water-stable soil structure (Arthur et al., 2011; Bazzoffi et al., 1998). The 

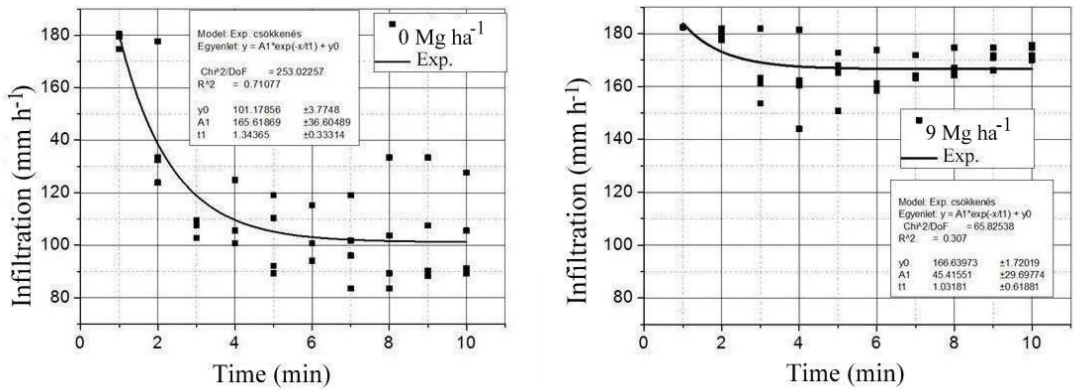

Fig. 3. Rate of water infiltration $\left(\mathrm{mm} \mathrm{h}^{-1}\right)$ on the control $\left(0 \mathrm{Mg} \mathrm{ha}^{-1}\right)$ and compost treated plot $\left(9 \mathrm{Mg}^{-1}\right)$ under high intensity rainfall $\left(185 \mathrm{~mm} \mathrm{~h}^{-1}\right)$

T a b l e 4. Results of measurements with rainfall simulator

\begin{tabular}{|c|c|c|c|c|c|}
\hline $\begin{array}{l}\text { Compost dose } \\
\qquad\left(\mathrm{Mg} \mathrm{ha}^{-1}\right)\end{array}$ & $\begin{array}{c}\text { The intensity of } \\
\text { simulated rainfall } \\
\left(\mathrm{mm} \mathrm{h}^{-1}\right)\end{array}$ & $\begin{array}{c}\text { Runoff } \\
\left(\mathrm{ml} \mathrm{m} \mathrm{m}^{-2} 10 \mathrm{~min}^{-1}\right)\end{array}$ & $\begin{array}{c}\text { Erosion } \\
\left(\mathrm{g} \mathrm{m}^{-2} 10 \mathrm{~min}^{-1}\right)\end{array}$ & $\begin{array}{l}\text { Erosion/rainfall } \\
\left(\mathrm{g} \mathrm{m}^{-2} \mathrm{~mm}^{-1}\right)\end{array}$ & $\begin{array}{l}\text { Soil erodibility } \\
\text { factor }(\mathrm{K})\end{array}$ \\
\hline 0 & \multirow{4}{*}{185} & $11040 \mathrm{~b}$ & $643 \mathrm{~b}$ & $21.4 \mathrm{a}$ & $0.449 \mathrm{~b}$ \\
\hline 9 & & $2164 \mathrm{a}$ & $76 \mathrm{a}$ & $2.5 \mathrm{a}$ & $0.052 \mathrm{a}$ \\
\hline 18 & & $196 \mathrm{a}$ & $8 \mathrm{a}$ & $0.3 \mathrm{a}$ & $0.005 \mathrm{a}$ \\
\hline 27 & & $122 \mathrm{a}$ & $5 \mathrm{a}$ & $0.2 \mathrm{a}$ & $0.003 \mathrm{a}$ \\
\hline
\end{tabular}

Explanations as in Fig. 1.

increase of water infiltration should be considered a consequence of increased total porosity in soil after compost application (Civeira, 2010; Weber et al., 2007).

The compost treatments, while increasing the intensity of infiltration, typically changed the slope of the infiltration characteristic curve as well. The phase of water transition and the stable phase were clearly separated in the control plot, but the separation of the two phases was not clear in the treatment with the lowest $\left(9 \mathrm{Mg} \mathrm{ha}^{-1}\right)$ compost dose (Fig. 3).

The results show a clear relationship in the runoff and erosion behaviour of the different compost treatments and the control (Table 4). The runoff and water erosion on sandy soil were significantly reduced by the compost application. In earlier studies was reported that the aggregate stability is negatively correlated with erosion and runoff (Barthes and Roose, 2002; Kroulík et al., 2010). Thus, the application of sewage sludge compost improves the structure of sandy soil. The improved physical properties by organic matter addition are affected by increased microbial activity (Aggelides and Londra, 2000; Tejada and Gonzalez, 2006). Soil bacteria and fungal hyphae play a significant role by binding soil particles into aggregates (Miller and Jastrow, 2000; Ortas, 2002). This statement was confirmed by the results of Makádi (2010) who reported increased quantity of soil microbes and an increase in the invertase and catalase activities of the sandy soil in our experiment.

\section{CONCLUSIONS}

1. Addition of compost reduced soil bulk density and increased air permeability significantly. However, due to mineralisation processes, beneficial effects of organic matter decreased with time. Only the highest compost dose $\left(27 \mathrm{Mg} \mathrm{ha}^{-1}\right)$ had a long-term effect on the studied soil properties.

2. Based on our results, strong negative linear correlation $\left(\mathrm{R}^{2}=-0.54\right)$ was found between bulk density and air permeability of the soil, the decrease/increase in bulk density $\left(0.1 \mathrm{~g} \mathrm{~cm}^{-3}\right)$ causing approximately a $30 \%$ increase/ decrease in air permeability.

3. It was proved that the compost treatment had a beneficial effect on soil structure, thereby significantly reducing the runoff and water erosion under simulated high intensity rainfall. The beneficial effect of compost application on soil structure can be more expressed in the future when, as a result of climate change in the Carpathian Basin, the increasing frequency of high-intensity precipitation events could cause major erosion damage on sandy hills.

4. The experiment indicated that composting can be a solution for treatment of sewage sludge, which is considered as a waste, and that the compost can be utilised in agriculture in an environmentally-sound way. However, the beneficial effect of composted sewage sludge lasts only for two years, which was especially expressed in the sandy soil.

Conflict of interest: The Authors do not declare conflict of interest. 


\section{REFERENCES}

Adani F., Tambone F., and Genevini P., 2009. Effect of compost application rate on carbon degradation and retention in soils. Waste Management, 29, 74-179.

Aggelides S.M. and Londra P.A., 2000. Effect of compost produced from town wastes and sewage sludge on the physical properties. Bioresource Technology, 71, 253-259.

Angin I., Aksakal E.L., Oztas T., and Hanay A., 2013. Effects of municipal solid waste compost (MSWC) application on certain physical properties of soils subjected to freeze thaw. Soil Tillage Res., 130, 58-61.

Aranyos T., Tomócsik A., Orosz V., Makádi M., Antal K., and Blaskó L., 2014. Bulk density and air-permeability of a sandy soil treated with sewage sludge compost in a longterm field experiment (in Hungarian). Agroch. Soil Sci., 63(2), 269-282.

Arthur E., Cornelis W.M., Vermang J., and De Rocker E., 2011. Effect of compost on erodibility of loamy sand under simulated rainfall. Catena, 85, 67-72.

Barthes B. and Roose E., 2002. Aggregate stability as an indicator of soil susceptibility to runoff and erosion: Validation at several levels. Catena, 47, 133-149.

Bazzoffi P., Pellegrini S., Rocchini A., Morandi M., and Grasselli O., 1998. The effect of urban refuse compost and different tractors tyres on soil physical properties, soil erosion and maize yield. Soil Till. Res., 48, 275-286.

Birkás M., 2008. Environmentally-Sound Adaptable Tillage (in Hungarian). Academic Publisher, Budapest, Hungary.

Buzás I., 1993. Soil- and agrochemical methods manual I. (in Hungarian). INDA 4231 Publisher, Budapest, Hungary.

Celik I., Ortas I., and Kilic S., 2004. Effects of composts, mycorrhiza, manure and fertilizer on some physical properties of Chromoxerert soil. Soil Till. Res., 78, 59-67.

Civeira G., 2010. Influence of municipal solid waste compost on soil properties and plant reestablishment in Peri-Urban environments. Chilean J. Agric. Res., 70(3), 447-453.

Coffman S. and Rasic T.J., 2015. Rhyolite characterization and distribution in central Alaska. J. Archaeological Sci., 57, 142-157.

De O'na J., Osorio F., and Garcia P. A., 2009. Assessing the effects of using compost-sludge mixtures to reduce erosion in road embankments. J. Hazardous Materials, 164, 1257-1265.

Fister W., Iserloh T., Ries J.B., and Schmidt R.-G., 2011. Comparison of rainfall characteristics of a small portable rainfall simulator and a combined portable wind and rainfall simulator. Zeitschrift für Geomorphologie, 55(3), $109-126$.

Gondek K., 2009. Zinc Content in maize (Zea mays L.) and soils fertilized with sewage sludge and sewage sludge mixed with peat. Polish J. Environ. Studies, 18 (3), 359-368.

Hanász A., 2014. Changes in parameters related to organic matter content during the sewage sludge composting (in Hungarian). B. Sc. Thesis, University of Debrecen, Hungary.

Hemmat A., Aghilinategh N., Rezainejad Y., and Sadeghi M., 2010. Long-term impacts of municipal solid waste compost, sewage sludge and farmyard manure application on organic carbon, bulk density and consistency limits of a calcareous soil in central Iran. Soil Till. Res., 108, 43-50.
Iserloh T., Fister W., Ries J.B., Cerdá A., Echeverría M.T., Geissler C., Kuhn N.J., León F.J., Peters P., Schindewolf M., Schmidt J., Scholten T., and Seeger M., 2012. Comparative measurements with seven rainfall s simulators on uniform bare fallow land. Zeitschrift für Geomorphologie, 57(1), 11-26.

Iversen B.V., Schjønning P., Poulsen T.G., and Møldrup P., 2001. In-situ, on-site and laboratory measurements of soil air permeability. Boundary conditions and measurement scale. Soil Science, 166, 97-106.

Kamphorst A., 1987. A small rainfall simulator for the determination of soil erodibility. Netherlands J. Agric. Sci., 35, 407-415.

Kroulík M., Brant V., Masek J., and Kavarícek P., 2010. Influence of soil tillage treatment and compost application on soil properties and water infiltration. Czech University of Life Sciences: Trends in Agricultural Engineering, 343-349.

Liu T., Liu B., and Zhang W., 2014. Nutrients and Heavy Metals in Biochar Produced by Sewage Sludge Pyrolysis: Its Application in Soil Amendment. Polish J. Environ. Studies, 23(1), 271-275.

Makádi M., 2010. Microbiological properties of sandy soils in the Nyírség region (Hungary), affected by organic and inorganic additives (in Hungarian). Ph.D. Thesis, University of Szent Istvan, Gödöllö, Hungary.

Miller R.M. and Jastrow J.D., 2000. Mycorrhizal fungi influence soil structure. In: Arbuscular Mycorrhizas: Physiology and Function (Eds Y. Kapulnik, D. D. Douds). Kluwer Academic Publishers, Dordrecht, Netherlands.

Mylavarapu R.S. and Zinati G.M., 2009. Improvements of soil properties using compost for optimum parsley production in sandy soils. Scientia Horticulturae, 120, 426-430.

Ortas I., 2002. Biological, degradation. In: Encyclopedia of Soil Science (Ed. R. Lal). Marcel Dekker, USA.

Sánchez de Cima D., Luik A., and Reintam E., 2015. Organic farming and cover crops as an alternative to mineral fertilizers to improve soil physical properties. Int. Agrophys., 29, 405-412.

Suzuki S., Noble D.A., Ruaysoongnern S., and Chinabut N., 2007. Improvement in water-holding capacity and structural stability of a sandy soil in Northeast Thailand. Arid Land Research and Management, 21(1), 37-49.

Tejada M. and Gonzalez J.L., 2006. Influence of organic amendments on soil structure and soil loss under simulated rain. Soil Till. Res., 91, 186-198.

Tejada M., Gonzalez J.L., Garcia-Martinez A.M., and Parrado J., 2008. Application of a green manure and green manure composted with beet vinasse on soil restoration: Effects on soil properties. Bioresource Technol., 99, 4949-4957.

Várallyay G., 2005. Soil water management and the environment. In: Environmental Science and Technology in Hungary (Ed. I. Láng). MEW, Budapest, Hungary.

Weber J., Karczewska A., Licznar M., Drozd J., Jamroz E., and Kocowicz A., 2007. Agricultural and ecological aspects of a sandy soil as affected by the application of municipal solid waste composts. Soil Biology Biochem., 39, 1294-1302.

Wischmeier W.H. and Smith D.D., 1978. Predicting rainfall erosion losses. USDA Agriculture Handbook 537, Washington, DC., USA. 